\title{
CREATIVITY FOR GAINING AND SUSTAINING COMPETITIVE ADVANTAGE: THE ROLE OF LEADERSHIP STYLES
}

\author{
*F. Oben ÜRÜ \\ **Uğur YOZGAT
}

*Haliç University, Turkey

**Marmara University, Turkey

\begin{abstract}
The main object of this paper is to examine the effect of leadership styles on employee creativity. Thus the research was performed in Iron and Steel, Automotive and Textile industries listed in Istanbul Chamber of Industry's Turkey's Top 500 Industrial Enterprises 2008. As the results of analyses, transformational, transactional and laissez-faire leadership styles have effect on employee creativity (64\%), controlling creative personality. Also results show that creative personality had a strong explanatory effect on employee creativity (54,5\%). It is determined that, "Challenge \& Enjoyment" partially mediated the relationship between leadership styles and employee creativity and it increased employee creativity 16,9\%. In addition Climate for Creativity partially mediated the relationship between leadership styles and employee creativity, and it increased employee creativity 14, 9\%. On the other hand, Compensation partially moderated between transactional leadership and employee creativity and between transformational leadership and employee creativity; Acceptance partially moderated between transactional leadership and employee creativity, and Goal Setting partially moderated between transformational leadership and employee creativity. Results also show that Compensation had a negative association with creativity. Finally, it was seen that Conservation partially moderated between transformational leadership and employee creativity. This study's theoretical contribution is examination of effects of leadership styles on employee creativity in a comprehensive model; proposing new mediating and moderating variables in this correlation and filling this gap in the research. Furthermore, this study's practical contribution is there is lack of research that consists of stated variables in our model conducted such a wide scope. And finally, this study offers a methodological contribution to empirical studies on employee creativity under different leadership styles to developing countries like Turkey, as it shows the external validity of these theories which were developed and investigated in Western developed countries.
\end{abstract}

Key Words: Leadership Styles, Employee Creativity, Intrinsic and Extrinsic Motivation, Creative Personality

\section{INTRODUCTION}

The depth, breadth, and speed of change that engulfs businesses today, and trends such as globalization, technology advancement, and the knowledge-based economy have put increasing pressure on business creativity and innovation (Ford \& Gioia, 1995; Kim \& Mauborgne, 2005). A number of factors have resulted in creativity becoming more critical across jobs and organizations. For example, creativity has become and will remain indispensable as organizations and their environments 
change fundamentally (Ford \& Gioia, 1995), and as jobs become more complex and work designs include more autonomy (Oldham \& Cummings, 1996). In order to survive, adapt, and gain competitive advantage, organizations need to unleash their employees' innate creative potential, because employees' creative ideas can be used as building blocks for organizational innovation, change, and competitiveness (Amabile, 1988; Woodman, Sawyer \& Griffin, 1993, Zhou \& George, 2003). Gupta and Singhal (1993) found that successful organizations create competitive advantage in the marketplace through innovation by revealing their employees' creativity. If we view employees as resources in the competitive marketplace, the question then becomes how their creativity can be fostered for the organization's purpose. Until recently, research on employee creativity focused on identifying personal characteristics and work environment that related to creative performance. Although many variables influence employees' creativity in organizational settings, there is reason to suspect that leaders and their behavior represent a particularly powerful influence. The role of the leadership in employee creativity has been researched by organizational scholars in this decade. Research shows that leaders have at their disposal various means to influence creativity in their organizations (Mumford, Scott, Gaddis, \& Strange, 2002) and leaders could influence their followers' creativity by altering their leadership style into transformational leadership to expose their creativity (Jung \& Avolio, 1999; Kahai, Sosik, \& Avolio, 1997; Sosik, Avolio, \& Kahai, 1997, 1998; Sosik, Kahai, \& Avolio, 1998). Thus, employees' creativity can be fostered for the organization's purpose. Furthermore, most of the research has been conducted in Western countries, primarily in the United States. From the literature review, it is seen that there is lack of research about the role of leadership styles on employee creativity in Turkey. Given the lack of academic research about this topic in Turkey, the aim of this study is to examine the effect of leadership styles on employee's creativity, focusing on the Turkey's Top 500 Industrial Enterprises. In addition, this study analyzes personal characteristics (eg. creative personality, intrinsic motivation, conservation) and work environment (climate for creativity, extrinsic motivation) in this relation. Figure 1 shows our model developed for this purpose.

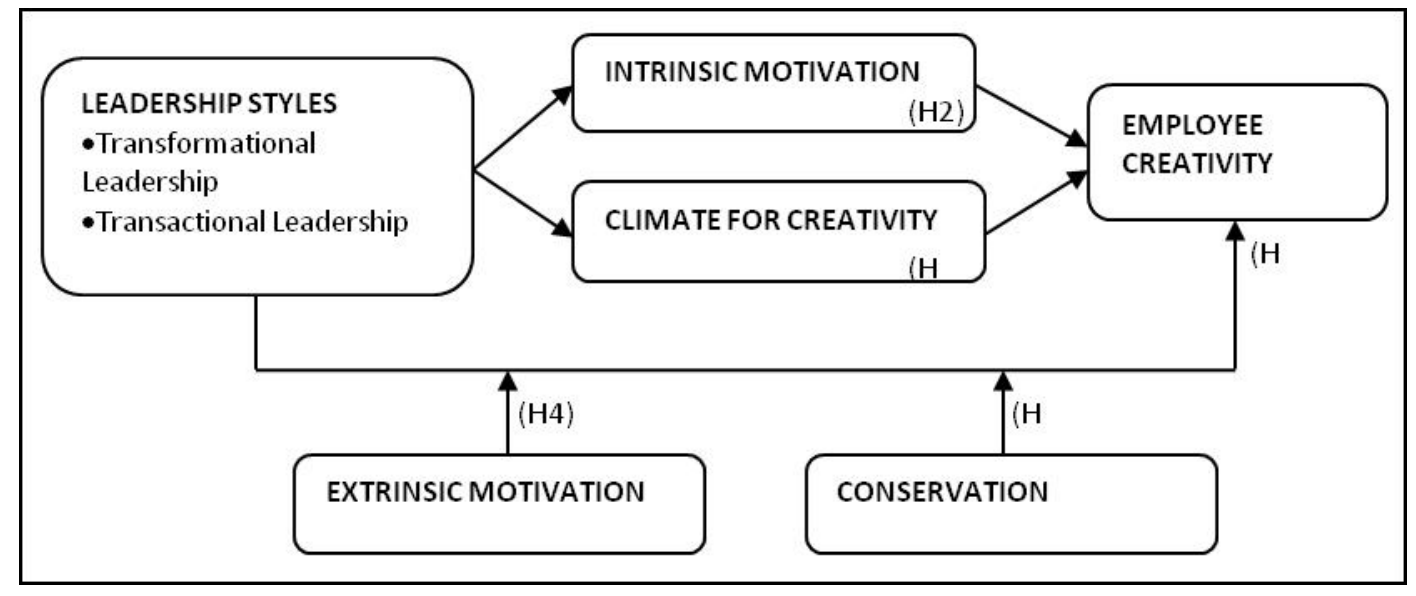

Figure 1: The Proposed Model

According to the proposed model, leadership styles effect on employee creativity $\left(\mathrm{H}_{1}\right)$. Employees' intrinsic motivation and climate for creativity mediate this effect $\left(\mathrm{H}_{2}, \mathrm{H}_{3}\right)$. Furthermore, extrinsic motivation and conservation moderate in this effect $\left(\mathrm{H}_{4}, \mathrm{H}_{5}\right)$. On top of all this, our model proposes control variables like creative personality, educational level, and job tenure since they are related to creativity. 


\section{THEORETICAL BACKGROUND AND HYPOTHESES Employee Creativity and Leadership Styles}

Creativity has been an important topic in our global world as well as in the social sciences for last decades. There has been a growing consensus among creativity researchers regarding the appropriateness of defining creativity in terms of an outcome (Amabile, 1983) such as an idea or product (Amabile, 1988; Woodman, Sawyer \& Griffin, 1993). Nonetheless, Amabile's definition of creativity as the "production of novel and useful ideas" (1988:126) has been cited and used in many studies, and has become the most common one (e.g. Oldham \& Cummings, 1996; Tierney, Farmer \& Graen, 1999; Prabhu, Sutton \& Sauser, 2008). Consistent with these studies, we defined creativity as the generation of novel, unique, and original ideas that are related to processes and procedures used in workplace. The bulk of research on creativity over the years has emphasized the examination of employee creativity in workplace (e.g. Amabile, 1988; Oldham \& Cummings, 1996; Woodman, Sawyer \& Griffin, 1993) as it relates to companies' competitive advantage. Since employees' creativity has seen as a requirement for innovation as well as surviving and adapting in challenging world, and gaining competitive advantage, many researchers seek to find what effects employees' creativity and in which conditions employees' creative performance can be increased. Research refers to leaders' behaviors have a powerful effect and noticeable impact on followers creativity. Therefore, this study examines the leadership styles' effect on employees' creativity. Before digging into the research determining the relationship between employees' creativity and leadership styles, it would be appropriate to give the definition of leadership and expansion of leadership styles.

In the literature, many authors which have interest in studying topic of leadership, offered definitions of leadership and defined this concept as a complex process by which a person influences others, applying his/her leadership attributes like belief, values, ethics, character, knowledge and skills, to accomplish a mission, task or objective and directs the organization in a way that makes it more cohesive and coherent (Yukl, 1989:252; Boune \& Kurtz, 1990:183; Nelson \& Quick, 1994:358; Cook, Hunsaker \& Coffey, 1997:463; Greenberg \& Baron, 2000:445). In addition to, it is seen that there are differences in connection with the types of leadership. Burns (1978) was one of the firsts to identify two types of leadership styles, transformational and transactional. Further these leadership styles refined by Bass (1985). Furthermore, accepted common theory about leadership styles came from Bass \& Avolio (1995). According to them, leadership styles consist of transformational, transactional and laissez-faire leadership. As to them, transformational leaders motivate others to do more than they originally intended and often even more than they thought possible. They set more challenging expectations and typically achieve higher performances (Bass \& Avolio, 1994:3). Factor analytic study by Bass \& Avolio (1995) has suggested that transformational leadership can be conceptually organized along four correlated dimensions: charisma-idealized influence, inspirational motivation, intellectual stimulation and individualized consideration. Using charisma, the leader inspires admiration, respect, and loyalty, and emphasizes the importance of having a collective sense of mission. By inspirational motivation, the leader creates a clear picture of the future state that is both optimistic and attainable, and encourages others to raise their expectations, reduces complexity to key issues and uses simple language to convey the mission. By intellectual stimulation, leaders stimulate their followers' efforts to be innovative and creative by questioning assumptions, reframing problems, and approaching old situations in new ways. By individualized consideration, leaders pay special attention to each individual's needs for achievement and growth by acting as coach or mentor (Bass \& Avolio, 1994:3). According to Bass \& Avolio (1994:4) transformational leadership 
is an expansion of transactional leadership. Transactional leadership emphasizes the transaction or exchange that takes place among leaders, colleagues, and followers. This exchange is based on the leader discussing with others what is required and specifying the conditions and rewards these others will receive if they fulfill those requirements. That is to say, transactional leadership occurs when the leader rewards or disciplines the follower depending on the adequacy of the follower's performance. Transactional leadership diverges from transformational leadership in that the transactional leader does not individualize the needs of subordinates nor focus on their personal development (Northouse, 2001:140). In other words, transactional leader motivates subordinates to perform as expected while the transformational leader typically inspires followers to do more than originally expected (Hartog \& Van Muijen, 1997:21). Transactional leadership depends on contingent reinforcement, either positive contingent reward $(C R)$ or the more negative active or passive forms of management by exception (MBE-A or MBE-P). By contingent reward, the leader assigns or gets agreement on what needs to be done and promises rewards or actually rewards others in exchange for satisfactorily carrying the assignment (Bass \& Avolio,1994:4). Leaders who practice management by exception have implicit trust in their workers to finish the job to a satisfactory standard. These leaders do not inspire the workers to achieve beyond expected outcomes (Santora \& Sarros, 2001:389). By MBE-A, the leader actively seeks to deviations from rules and standard procedures and takes corrective action when irregularities occur. On the other hand, by MBE-P, the leader take action after deviations and irregularities have occurred and standards are not met (Bass \& Avolio, 1994:4). The difference between the two is that in MBE-A, the leader search for deviations, whereas in MBE-P the leader waits for problems to materialize (Bass, 1990; Lowe \& Galen Kroeck, 1996; Hartog \& Van Muijen, 1997). In essence, both MBE-A and MBE-P types use more negative reinforcement patterns than positive reinforcement pattern described under contingent reward (Northouse, 2001:141). The laissez-faire style is the avoidance or absence of leadership and is, by definition, the most inactive - as well as the most ineffective according to almost all research on the style (Bass \& Avolio, 1994:4). There is a negative association between laissez-faire leadership and a variety of subordinate performance, and effort indicators, which implies that laissez-fare leadership is an inappropriate way to lead. By laissez-faire it is meant that the leader is not sufficiently motivated or adequately skilled to perform supervisory duties. While this statement seems to be correct, there are also situations in which highly active leadership is not necessary. Hartog \& Van Muijen (1997) state that a less active role of leaders could also lead to empowerment of followers which could even make for a useful component of transformational leadership.

After revealing the leadership literature, it will be convenient to represent some of the studies examining the leadership effect on followers' creativity. In the literature, it is seen that leadership behaviors closely match the determinants of creativity at the workplace, some of which are vision, support for creativity, encouragement and challenge. For example, Bass \& Avolio (1995) and Sosik, Kahai, \& Avolio (1998) determined in their studies that leader's behaviors especially transformational one, are likely to act as "creativity-enhancing forces": individualized consideration "serves as a reward" for the followers by providing recognition and encouragement; intellectual stimulation "enhances exploratory thinking" by providing support for creativity and challenge, and inspirational motivation "provides encouragement into the idea generation process" by energizing followers to work towards the organization's vision. On the other hand, by highlighting desirable outcomes that would result from a successful discussion (e.g. a long list of ideas, a feeling of satisfaction), a transactional leader can build effort-accomplishment expectancies to extrinsically motivate creativity-relevant contributions to the employees (Kahai, Sosik, \& Avolio, 2003:503). However Jung (2000:188) stated that there are no active and intentional efforts made by the transactional leader to enhance followers' 
creativity. Followers are extrinsically motivated to perform their job under the transactional leader, which may hold creativity at the minimal level (Amabile, 1998).

On the basis of the previous discussion and examination of the research concerned with employee creativity and leadership styles, the following hypothesis is advanced: $\mathbf{H}_{\mathbf{1}}$ : Leadership styles effect on employee creativity. Namely, transformational leadership has more positive effect on employee creativity than transactional and laissez-faire leadership.

\section{Intrinsic\&Extrinsic Motivation, Employee Creativity and Leadership Styles}

In the literature it seen that there are two types of motivation; extrinsic and intrinsic. Intrinsic motivation represents a motivational situation in which employees performs a task due to the sheer fascination of the task itself, rather than for the external outcomes or rewards related to the task whereas external motivation occurs when a task is related to these external outcomes or rewards (Deci \& Ryan, 1985). Research show intrinsic motivation is the key ingredient in the creativity (Amabile, 1988, 1998, Amabile et al., 1996). To the effect that, while an employee is intrinsically attracted to a task, he/she is more likely to focus on it explore and experiment with it, hence exhibit more creative performance and behavior (Tierney, Farmer \& Graen, 1999). Oldham \& Cummings (1996) specified leader behaviors are important determinants of intrinsic motivation and creativity at work. For example, transformational leaders who care for their employees' feelings and needs, facilitate their skill development, show them ways to achieve the goals and express confidence in them are likely to enhance their employees' interest in their tasks.

Based on the discussion above, this study proposes that leadership styles affect employee creativity through intrinsic motivation. Therefore, $\mathbf{H}_{2}$ : Intrinsic motivation mediates the relationship between leadership styles and employee creativity.

On top of all this, research shows extrinsic motivation also has an incremental effect on creativity (Eisenberger, Rhoades \& Cameron, 1999; Eisenberger \& Rhoades, 2001; Prabhu, Sutton \& Sauser, 2008). Some researchers stated intrinsic motivation has more effect on employee creativity than extrinsic motivation (Amabile, 1983; Hennessey \& Amabile, 1988). Deci (1971) specified under certain conditions extrinsic motivation has a negative impact on intrinsic motivation. In addition to, Prabhu, Sutton \& Sauser (2008) found extrinsic motivation had a negative impact on creativity when extrinsic motivation at high levels. However, more recent studies have not only negated some of the prior research about the negative impact of extrinsic motivation on creativity, on the contrary, have found that, under certain circumstances, extrinsic motivation was positively related to creativity (Prabhu, Sutton \& Sauser, 2008:57, Mumford, Scott, Gaddis, \& Strange, 2002). Consequently, there are tasks and duties challenging and interesting (intrinsically motivating) at workplace but there are

also tasks which are extrinsically motivated (Prabhu, Sutton \& Sauser, 2008:57). Furthermore, as seen in the research, intrinsic and extrinsic motivation could aid employees' creativity. Intrinsic motivation could be essential for the novelty in the work, although extrinsic motivation can help to ensure a timely and complete output (Prabhu, Sutton \& Sauser, 2008:57). Hence, the following hypothesis is advanced: $\mathbf{H}_{\mathbf{4}}$ : Extrinsic motivation moderates the relationship between leadership styles and employee creativity. 


\section{Climate for Creativity, Employee Creativity and Leadership Styles}

In the literature, many authors defined climate as a cognitive interpretation of an organizational situation that has been labeled "psychological climate". Climate represents signals individuals receive concerning organizational expectations for behavior and potential outcomes of behavior (Scott \& Bruce, 1994:582). And research show organizational climate affect employees' creativity (Siegel \& Kaemmerer, 1978; Scott \& Bruce, 1994; Amabile et al., 1996). Scott \& Bruce (1994) specified organizational climate is an important factor for creativity since employees' perceptions of the extent to which creativity is encouraged at the workplace, and the extent to which organizational resources are allocated to supporting creativity influence creative performance. In addition to, employees' perceptions of a creative climate encourages risk-taking and the challenge to use creative approaches at work. Hence, Scott \& Bruce (1994) found that existing climate for creativity enhances employee creativity through adequate supplies of resources such as time, equipment, and facilities are critical to employee creativity. On top of all this, research refers leadership styles also have an important effect on employee creativity through its influence on the employees' perceptions of a climate supportive of creativity. Amabile, et al. (1996) and Scott \& Bruce (1994) stated the leader can establish a work environment encouraging creativity and create an organizational climate that serves as a guiding principle for more creative work processes. Especially transformational leaders could establish a climate where employees feel challenged and energized to seek creative behaviors for their tasks and duties by intellectually stimulating employees' efforts to be innovative and creative through questioning assumptions, reframing problems, and approaching old situations in new ways and articulating a compelling vision throughout the organization. According to these findings, this study proposes that leadership styles affect employee creativity through creative climate. Therefore, $\mathrm{H}_{3}$ : Climate for creativity mediates the relationship between leadership styles and employee creativity.

\section{Conservation, Employee Creativity and Leadership Styles}

Individual beliefs, values and norms effect the relation between leader and follower (Yukl, 1992; Bass, 1997:137). Namely, different employees could evaluate same leader in different ways and react his/her differently. In this context, research refers employees who value conformity, security, and tradition affiliate themselves with their leader (Schwartz, 1994, 1999; Ros, Schwartz \& Surkiss, 1999). Employees having "basic individual values" such as conformity, security, and traditionnamed conservation by Schwartz (1992)-could react positively to the leadership especially to transformational leadership (Jung \& Avolio, 1999; Shin \& Zhou, 2003). In addition to, values and self concepts act as intervening mechanisms by which leaders influence followers (Lord \& Brown, 2001). In contrast to these findings, recent studies (e.g. Kasof et al., 2007) show that creative behavior is discouraged primarily by the tradition value type and secondarily by the conservation conformity and security value types-. In the present study, we addressed these different findings in the literature, and wanted to ascertain whether creative behavior is prevented or promoted by conservation. Hence the moderating role of conservation is hypothesized: $\mathbf{H}_{5}$ : Conservation moderates the relationship between leadership styles and employee creativity. 


\section{METHODOLOGY}

\section{The Main Objective and Scope of the Research}

The main objective of this research is to examine the effect of leadership styles on employee creativity. This research comprises industrial enterprises in Iron and Steel, Automotive and Textile Industries listed in Istanbul Chamber of Industry's Turkey's Top 500 Industrial Enterprises 2008. In this context, white collar employees' opinions and attitudes are taken as base.

\section{Data Collection Method, Procedures and Type of Research}

This study was performed by explanatory research model. According to this, the effects of leadership styles on employee creativity were explained and identified. The population of this study was composed of Turkey's Top 500 Industrial Enterprises listed in Istanbul Chamber of Industry's Turkey's Top 500 Industrial Enterprises 2008. Research sample consisted of 187 enterprises of Iron and Steel, Automotive and Textile industries listed in Istanbul Chamber of Industry's Turkey's Top 500 Industrial Enterprises 2008. Data were collected through structured questionnaires. In this research all of the 187 enterprises in the Turkey's Top 500 Industrial Enterprises list of stated industries are reached via e-mail and telephone. The questionnaires are given all of the specified enterprises through face-to-face interviews or via postal 100 each. But some of the participants excused for not answering the questionnaires by reason of their workload or length of the questions in the questionnaire. Hence 187 of 85 specified enterprises returned; thereby 85 specified enterprises of 3548 employees' answers included in this research. Details of dispersion of the questionnaires to the industries are exhibited in Table 1.

Table 1. Dispersion of the Questionnaires to the Industries

\begin{tabular}{|l|c|c|c|c|}
\hline INDUSTRIES & $\begin{array}{c}\text { Population } \\
\text { (Total Number of } \\
\text { Enterprises) }\end{array}$ & $\begin{array}{c}\text { Sample Size } \\
\text { (Number of the Enterprises } \\
\text { Answered the } \\
\text { Questionnaire*) }\end{array}$ & $\begin{array}{c}\text { Sampling } \\
\text { Ratio } \\
(\mathbf{\%})\end{array}$ & $\begin{array}{c}\text { Number of the } \\
\text { Employees } \\
\text { Answered the } \\
\text { Questionnaire** }\end{array}$ \\
\hline Iron and Steel Industry & 77 & 37 & 48,05 & 1491 \\
\hline Automotive Industry & 49 & 23 & 46,94 & 1025 \\
\hline Textile Industry & 61 & 25 & 40,98 & 1032 \\
\hline TOTAL & $\mathbf{1 8 7}$ & $\mathbf{8 5}$ & $\mathbf{4 5 , 4 5}$ & $\mathbf{3 5 4 8}$ \\
\hline
\end{tabular}

*Minimum 30, maximum 85 questionnaires returned from each enterprises answering questionnaire.

**Number of the employees answered the questionnaire consists of employees answering questions in the questionnaire completely and consistently (questionnaires with missing and inconsistent statements were excluded)

\section{Measures}

The questionnaire prepared for white collar employees, consisted of 150 questions in 7 parts for measuring sample's demographic characteristics and variables proposed in the research model; thereby in this research 6 different scales were used. In the first part of the questionnaire, for measuring leadership style (Independent Variable) Bass and Avolio's MLQ: Multifactor Leadership Questionnaire was used. MLQ is first developed in 1985 since then it had been improved several times. In this study, MLQ $5 \mathrm{X}^{3}$ translated into Turkish by Yurtkoru (2001) was used. This question- 
naire had three dimensions, 36 items all together and measured on a 5 point scale. These dimensions can be seen in Figure 1. In the second part, intrinsic and extrinsic motivation were measured on a 4 point scale by 30 items of WPI: The Work Preference Inventory adapted from Amabile et al. (1994). In the third part, for measuring climate that support creativity, Scott and Bruce's (1994) Climate for the Innovation Measure which has 22 items was used and measured on a 5 point scale. In the fourth part, conservation was measured on an 8 point scale by 16 items of human values test adapted from Schwartz (1992). In the fifth part, creative personality (control variable) was measured by 30 adjectives of CPS: Creative Personality Scale adapted from Gough (1979). In the sixth part, employee creativity (Dependent Variable) was measured on a 7 point scale by 11 items of Creativity Measure (Self Report) adapted from Muñoz-Doyague et al.(2008). And finally in the last part, demographic questions for measuring descriptives and other control variables such as educational level, and job tenure are asked. Permissions from authors developed these scales for using in the research was granted.

\section{Statistical Analysis}

In the direction of testing of the research model and purpose of the research, SPSS 16.0 Statistical Package and following statistical analysis were used. First, for measuring participants' demographic characteristics frequency analyses were done. Second, factor and reliability analyses were performed towards the determination of the factor structures and internal consistencies of the scales. In this context, exploratory factor analysis using principal components method and varimax rotation was conducted on the items of the scales. Third, to determine means, standard deviations and to understand correlations among all factors came out in the factor analysis, descriptive statistics, and Pearson correlation analysis were performed. And last, testing of the effects of the independent variables upon the dependent variables and mediating/moderating effects, multiple regression analyses and hierarchical regression analyses were conducted.

\section{FINDINGS}

\section{Frequency Analysis}

Demographic questions were analyzed according to frequency. In Table 2, frequency analysis shows the sample of the questionnaire. 
Table 2. Sample's Demographic Characteristics

\begin{tabular}{|c|c|c|c|c|c|c|c|c|c|}
\hline \multirow{2}{*}{$\begin{array}{l}\text { DEMOGRAPHIC } \\
\text { CHARACTERISTICS } \\
\end{array}$} & \multirow{2}{*}{$\begin{array}{l}\text { CATEGORIES } \\
\text { OF VARIABLES } \\
\end{array}$} & \multicolumn{2}{|c|}{$\begin{array}{l}\text { IRON AND STEEL } \\
\text { INDUSTRY }\end{array}$} & \multicolumn{2}{|c|}{$\begin{array}{l}\text { AUTOMOTIVE } \\
\text { INDUSTRY }\end{array}$} & \multicolumn{2}{|c|}{$\begin{array}{l}\text { TEXTILE } \\
\text { INDUSTRY }\end{array}$} & \multicolumn{2}{|c|}{ GENERAL } \\
\hline & & f & $\%$ & f & $\%$ & f & $\%$ & f & $\%$ \\
\hline \multirow[b]{2}{*}{ Gender } & Female & 368 & 75,3 & 176 & 17,2 & 223 & 21,6 & 767 & 21,6 \\
\hline & Male & 1123 & 24,7 & 849 & 82,8 & 809 & 78,4 & 2781 & 78,4 \\
\hline \multirow[b]{3}{*}{ Age } & $21-29$ & 179 & 12 & 315 & 30,7 & 339 & 32,8 & 833 & 23,5 \\
\hline & $30-40$ & 749 & 50,2 & 632 & 61,7 & 587 & 56,9 & 1968 & 55,5 \\
\hline & $41-58$ & 563 & 37,8 & 78 & 7,6 & 106 & 10,3 & 747 & 21 \\
\hline \multirow[b]{3}{*}{ Marital Status } & Single (Unmarried) & 224 & 15 & 260 & 25,4 & 269 & 26,1 & 753 & 21,2 \\
\hline & Married & 1158 & 77,7 & 738 & 72 & 743 & 72 & 2639 & 74,4 \\
\hline & Widowed & 109 & 7,3 & 27 & 2,6 & 20 & 1,9 & 156 & 4,4 \\
\hline \multirow[b]{7}{*}{ Educational Level } & Elementary School & - & - & - & - & 3 & 0,3 & 3 & 0,1 \\
\hline & Secondary School & - & - & - & - & 4 & 0,4 & 4 & 0,1 \\
\hline & High School & 107 & 7,2 & 28 & 2,7 & 70 & 6,8 & 205 & 5,8 \\
\hline & Vocational School & 461 & 30,9 & 182 & 17,8 & 209 & 20,3 & 852 & 24 \\
\hline & University & 803 & 53,8 & 671 & 65,5 & 661 & 64,1 & 2135 & 60,1 \\
\hline & Master's & 119 & 8 & 142 & 13,9 & 85 & 8,2 & 346 & 9,8 \\
\hline & Doctorate & 1 & 0,1 & 2 & 0,1 & 3 & 0,3 & 3 & 0,1 \\
\hline \multirow[b]{16}{*}{ Department } & Research \& Development & 25 & 1,7 & 39 & 3,8 & 6 & 0,6 & 70 & 2 \\
\hline & Information Systems & 3 & 0,2 & 17 & 1,6 & 12 & 1,2 & 32 & 0,9 \\
\hline & Foreign Trade & 117 & 7,8 & 100 & 9,8 & 50 & 4,8 & 267 & 7,5 \\
\hline & Administrative Affairs & 84 & 5,6 & 25 & 2,4 & 72 & 7 & 181 & 5,1 \\
\hline & Human Resources & 122 & 8,2 & 162 & 15,8 & 145 & 14 & 429 & 12,1 \\
\hline & Quality Improvement & 128 & 8,6 & 93 & 9,1 & 57 & 5,5 & 278 & 7,8 \\
\hline & Logistics & 22 & 1,4 & 29 & 2,9 & 1 & 0,1 & 52 & 1,4 \\
\hline & Financial Affairs & 148 & 10 & 17 & 1,7 & 89 & 8,6 & 254 & 7,1 \\
\hline & Marketing-Sales & 390 & 26,2 & 243 & 23,7 & 313 & 30,3 & 946 & 26,7 \\
\hline & Planning & 64 & 4,3 & 22 & 2,1 & 51 & 4,9 & 137 & 3,9 \\
\hline & Project Development & 5 & 0,3 & 29 & 2,8 & 9 & 0,9 & 43 & 1,2 \\
\hline & Purchasing & 74 & 5 & 30 & 2,9 & 41 & 4 & 145 & 4,1 \\
\hline & After Sales & - & - & 13 & 1,3 & 8 & 0,8 & 21 & 0,6 \\
\hline & Research Design & - & - & - & - & 10 & 1 & 10 & 0,3 \\
\hline & Technical & 15 & 1 & 8 & 0,8 & 7 & 0,7 & 30 & 0,8 \\
\hline & Production & 294 & 19,7 & 198 & 19,3 & 161 & 15,6 & 653 & 18,5 \\
\hline \multirow[b]{5}{*}{ Work Experience } & 6 month -5 years & 225 & 15,1 & 319 & 31,1 & 312 & 30,2 & 856 & 24,1 \\
\hline & $5,5-10$ years & 442 & 29,6 & 462 & 45,1 & 410 & 39,8 & 1314 & 37 \\
\hline & $11-15$ years & 405 & 27,2 & 185 & 18 & 221 & 21,4 & 811 & 22,9 \\
\hline & $16-20$ years & 291 & 19,5 & 57 & 5,6 & 84 & 8,1 & 432 & 12,2 \\
\hline & $21-48$ years & 128 & 8,6 & 2 & 0,2 & 5 & 0,5 & 135 & 3,8 \\
\hline \multirow{4}{*}{$\begin{array}{l}\text { Job Tenure } \\
\text { (In the Current Firm) }\end{array}$} & 4 month -3 years & 285 & 19,1 & 224 & 21,9 & 247 & 23,9 & 756 & 21,3 \\
\hline & 3,5 years -8 years & 715 & 48 & 584 & 57 & 623 & 60,4 & 1922 & 54,2 \\
\hline & $9-12$ years & 308 & 20,7 & 178 & 17,3 & 141 & 13,7 & 627 & 17,7 \\
\hline & $13-29$ years & 183 & 12,2 & 39 & 3,8 & 21 & 2 & 243 & 6,8 \\
\hline
\end{tabular}




\section{Factor and Reliability Analyses}

Multifactor Leadership Scale (MLQ). As a result of Cronbach's reliability analysis performed for MLQ, 3 items decreased the reliabilities were eliminated and the scale had a strong reliability (Cronbach's á= .969). Therefore factor analysis repeated. After factor analysis (principle component analysis with varimax rotation) was conducted, 3 factors which Eigenvalues $\geq 1$ obtained consisting of 33 items $\left(\mathrm{KMO}=0,943, X_{\text {Bartlet test }}^{2}(561)=116900 p=0,000\right)$. Total variance explained was \% 74,864 . Scale factors were found as in the original, so we named these factors like the original in turn; "Transformational Leadership (Cronbach á=.958, \% of Variance $=42,786$ )", "Transactional Leadership (Cronbach á=.894, \% of Variance $=21,731$ )", , "Laissez-Faire Leadership (Cronbach $\hat{a}=.84$, \% of Variance $=10,347)$ ".

Intrinsic Motivation Scale (WPI-IM). As a result of Cronbach's reliability analysis performed for intrinsic motivation, 2 items decreased the reliabilities were eliminated and the scale had a strong reliability (Cronbach's á $=.941)$. Therefore factor analysis repeated. After factor analysis was performed, 2 factors which Eigenvalues $\geq 1$ obtained consisting of 13 items (KMO=0,921, $X^{2}$ Bartlet test $(78)=37020 p=0,000)$. Total variance explained was $\% 67,896$. Scale factors were found unlike the original, so we named these factors in turn as; "Challenge and Enjoyment (Cronbach á=.94, \% of Variance $=45,009)$ ", "Self-Expression and Satisfaction (Cronbach á=.779, \% of Variance $=22,887$ )".

Extrinsic Motivation Scale (WPI-EM). As a result of Cronbach's reliability analysis performed for extrinsic motivation, 4 items decreased the reliabilities were eliminated and the scale had a reliability as Cronbach's á $=.723$. Therefore factor analysis repeated. After factor analysis was performed, 4 factors which Eigenvalues $\geq 1$ obtained consisting of 11 items $\left(K M O=0,689, X^{2}{ }_{\text {Bartlett test }}(55)=18360\right.$ $p=0,000)$. Total variance explained was $\% 76,347$. Scale factors were found unlike the original, so we named these factors in turn as; "Compensation (Cronbach á=.82, \% of Variance=23,602)", "Reward (Cronbach á=.769, \% of Variance =19,074)", "Acceptance (Cronbach á=.885, \% of Variance $=17,082)$ ", "Goal Setting (Cronbach á=.704, \% of Variance $=16,589)$ ".

Climate for Creativity Scale. As a result of Cronbach's reliability analysis performed for climate that support creativity, 3 items decreased the reliabilities were excluded and the scale had a strong reliability (Cronbach's á $=.972$ ). Therefore factor analysis repeated. After factor analysis was performed, 2 factors which Eigenvalues $\geq 1$ obtained consisting of 19 items $\left(\mathrm{KMO}=0,941, X_{\text {Bartlett test }}^{2}\right.$ $(171)=81250 p=0,000)$. Total variance explained was $\% 73,744$. Scale factors were found unlike the original, so we named these factors in turn as; "Tolerance of Differences (Cronbach á=.947, \% of Variance $=36,901$ )", "Support for Creativity and Resource Supply (Cronbach á=.959, \% of Variance $=36,843)$ ".

Conservation Scale. As a result of Cronbach's reliability analysis performed for conservation, 7 items decreased the reliabilities were eliminated and the scale had a reliability as Cronbach's $a ́=.803$. Therefore factor analysis repeated. After factor analysis was performed, 1 factor which Eigenvalue $\geq 1$ like the original scale obtained consisting of 9 items $\left(\mathrm{KMO}=0,877, X^{2}{ }_{\text {Bartlett test }}\right.$ (36) $=10600 p=0,000$ ). Total variance explained was \%65,560.

Creativity Scale. As a result of Cronbach's reliability analysis performed for creativity, 2 items decreased the reliabilities were eliminated and the scale had a strong reliability (Cronbach's á $=.969$ ).Therefore factor analysis repeated. After factor analysis was performed, 1 factor which Eigenvalue $\geq 1$ like the original scale obtained consisting of 9 items $\left(\mathrm{KMO}=0,915, X_{\text {Bartlett test }}^{2}\right.$ (36) $=44700 p=0,000)$. Total variance explained was $\% 80,604$. 
Creative Personality Scale (CPS). Reliability of the CPS was calculated via a weighted composite technique generated by Oldham ve Cummings (1996). As a result of reliability analysis performed for creative personality, 8 adjectives decreased the reliabilities were excluded and the scale had a strong reliability (total alpha .856). Hence, in this study we used Creative Personality Scale consist ing of 22 adjectives. Therefore, 13 checked adjectives which describe highly creative people was given a value of "+1"; 9 checked adjectives which describe less creative people was assigned a value of "-1". The values were then summed to form a CPS index.

According to the Tukey's Test of Addivity, "Climate for Creativity" variable loaded on one factor and items were averaged; but, "Leadership Styles", "Intrinsic Motivation", "Extrinsic Motivation" variables were taken with their factors came out from factor analysis in the following analysis. All of the factor scores in the research were calculated via averaging. 


\section{Descriptive Statistics}

Table 3. Means, Standard Deviations, and Correlations ${ }^{\mathbf{a}}$

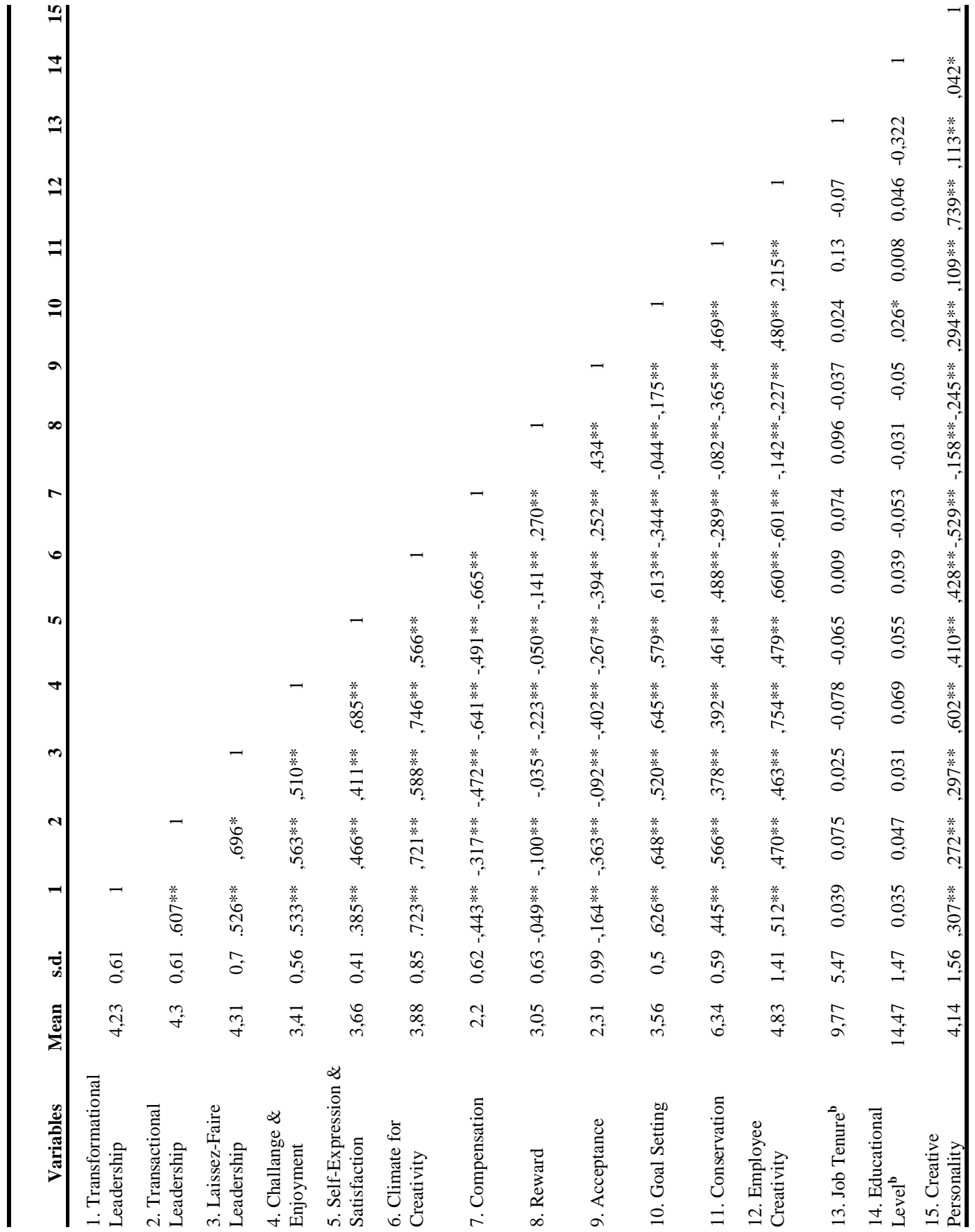

${ }^{a} \mathrm{~N}=3548$

${ }^{\mathbf{b}}$ Job Tenure is measured in years, Education is measured in years completed in the schools $* \mathrm{p}<0.05 * * \mathrm{p}<0.01$

Table 3 displays means, standard deviations, and correlations among all the variables. As it is seen, all variables except job tenure and educational level have correlations. Therefore only creative personality was taken as a control variable in the analysis (high correlation with employee creativity). 


\section{Regression Analyses}

To test research hypotheses, multiple regression analyses and hierarchical regression analyses were conducted. According to the correlations among the independent and mediator/moderator variables exhibited in Table 3 (and in collinearity statistics VIF values $<10$ ), Multicollinearity was not a severe problem that would preclude interpretation of the regression analyses. Also it is determined that there is no autocorrelation since Durbin-Watson test statistics values were close to 2. In this context, stepwise regression method was executed.

Hypothesis 1 relates to the direct effect of leadership styles on employee creativity. Therefore, $\mathrm{H}_{1}$ was tested using multiple regression analysis (See Table 4).

Table 4. Summary of Multiple Regression Analysis Predicting Effects of Leadership Styles on Employee Creativity

\begin{tabular}{llccccc}
\hline (Independent $)$ & Variables & $\begin{array}{c}\text { Adjusted } \\
\mathbf{R}^{2}\end{array}$ & $\mathbf{F}$ & $\mathbf{F ~ s i g . ~}$ & $\boldsymbol{\beta}$ & $\mathbf{P}$ \\
\hline $1^{\text {st }}$ Step: & $\begin{array}{l}\text { Creative } \\
\text { Personality }\end{array}$ & .545 & 4258 & .000 & .635 & .000 \\
$2^{\text {nd }}$ Step: & $\begin{array}{l}\text { Transformational } \\
\text { Leadership }\end{array}$ & .635 & 3091 & .000 & .197 & .000 \\
$3^{\text {rd }}$ Step: & $\begin{array}{l}\text { Laissez-Faire } \\
\text { Leadership }\end{array}$ & .639 & 2096 & .000 & .082 & .000 \\
$4^{\text {th }}$ Step: & $\begin{array}{l}\text { Transactional } \\
\text { Leadership }\end{array}$ & .640 & 1579 & .000 & .070 & .001 \\
\hline
\end{tabular}

Dependent Variable: Employee Creativity

As exhibited in Table 4, all leadership styles have effect on employee creativity and explanatory rate of the model that has 4 variables is a good explanatory power as .64. Also, it was determined that creative personality had a strong explanatory effect on employee creativity (.545). Therefore, the findings support $\mathbf{H}_{1}$.

Hypothesis 2 and 3 relate to the direct effect of leadership styles on employee creativity and the mediators of this relationship. To test for mediation, Baron \& Kenny (1986) suggested a three-step procedure (meditational analysis procedure): (a) the mediator was regressed on the independent variable, (b) the dependent variable was regressed on the independent variable, and finally, (c) the dependent variable was regressed on both the independent variable and on the mediator. However, to test for complete mediation, the independent variable needs to be controlled in the third step. In this context, full (complete, perfect) mediation occurs when the direct effect of the independent variable in this last condition is reduced to zero, otherwise the mediating effect is partial (Baron \& Kenny,1986; Robins \& Greenland,1992). Hence, multiple regression was performed for step one, but for steps two and three a hierarchical linear regression was employed. 
Table 5. Summary of Regression Analyses Predicting the Mediating Role of Intrinsic Motivation in the Relation between Leadership Styles and Employee Creativity

\begin{tabular}{|c|c|c|c|c|c|c|}
\hline & Variables & $\begin{array}{l}\text { Adjusted } \\
\mathbf{R}^{2}\end{array}$ & $\mathbf{F}$ & F sig. & $\beta$ & $\mathbf{P}$ \\
\hline \multirow[t]{3}{*}{ Regression $1^{\text {1a }}$} & $\begin{array}{l}\text { Creative } \\
\text { Personality }\end{array}$ & .362 & 2012 & .000 & .469 & .000 \\
\hline & $\begin{array}{l}\text { Transactional } \\
\text { Leadership }\end{array}$ & .534 & 2036 & .000 & .345 & .000 \\
\hline & $\begin{array}{l}\text { Laissez-Faire } \\
\text { Leadership }\end{array}$ & .543 & 1405 & .000 & .131 & .000 \\
\hline \multirow[t]{4}{*}{ Regression $1^{2 a}$} & $\begin{array}{l}\text { Transactional } \\
\text { Leadership }\end{array}$ & .217 & 983,398 & .000 & .480 & .000 \\
\hline & $\begin{array}{l}\text { Creative } \\
\text { Personality }\end{array}$ & .304 & 774 & .000 & .306 & .000 \\
\hline & $\begin{array}{l}\text { Transformational } \\
\text { Leadership }\end{array}$ & .310 & 532,438 & .000 & -.243 & .000 \\
\hline & $\begin{array}{l}\text { Laissez-Faire } \\
\text { Leadership }\end{array}$ & .322 & 421,696 & .000 & .163 & .000 \\
\hline \multirow[t]{5}{*}{ Regression $2^{\mathrm{b}}$} & $\begin{array}{l}\text { Step } 1 \text { (exhibited } \\
\text { in Table 4) }\end{array}$ & .640 & 1579 & .000 & .070 & .001 \\
\hline & Step 2 & & & & & \\
\hline & $\begin{array}{l}\text { Challenge \& } \\
\text { Enjoyment }\end{array}$ & .568 & 4671 & .000 & .396 & .000 \\
\hline & $\begin{array}{l}\text { Creative } \\
\text { Personality }\end{array}$ & .696 & 4055 & .000 & .450 & .000 \\
\hline & $\begin{array}{l}\text { Transformational } \\
\text { Leadership }\end{array}$ & .714 & 2959 & .000 & .162 & .000 \\
\hline
\end{tabular}

${ }^{\text {1a }}$ Dependent Variable is Challenge \& Enjoyment. ${ }^{2 a}$ Dependent Variable is Self-Expression \& Satisfaction.

${ }^{\text {b }}$ Dependent Variable is Employee Creativity.

Hypothesis 2 suggested that intrinsic motivation mediated the relationship between leadership styles and employee creativity. As shown in Table 5, the regression coefficient for intrinsic motivation's factor "Challenge \& Enjoyment" was significant in contributing to employee creativity when leadership styles were controlled, indicating the mediating role of "Challenge \& Enjoyment". The significance of transformational leadership decreased in step 2 whereas transactional and laissez-faire leaderships did not enter into equation, which signified that "Challenge \& Enjoyment" partially mediated the relationship between leadership styles and employee creativity. Therefore, $\mathbf{H}_{\mathbf{2}}$ is supported. 


\section{Table 6. Summary of Regression Analyses Predicting the Mediating Role of Climate for Creativity in the Relation between Leadership Styles and Employee Creativity}

\begin{tabular}{|c|c|c|c|c|c|c|}
\hline & & Adjusted & & & & $\mathbf{P}$ \\
\hline & Variables & $\mathbf{R}^{2}$ & $\mathbf{F}$ & F sig. & $\beta$ & \\
\hline \multirow[t]{5}{*}{ Regression $1^{\mathrm{a}}$} & $\begin{array}{l}\text { Transformational } \\
\text { Leadership }\end{array}$ & .523 & 3894 & .000 & .310 & .000 \\
\hline & Creative & & & & & \multirow[t]{2}{*}{.000} \\
\hline & Personality & .570 & 2351 & .000 & .221 & \\
\hline & $\begin{array}{l}\text { Transactional } \\
\text { Leadership }\end{array}$ & .604 & 1806 & .000 & .360 & .000 \\
\hline & $\begin{array}{l}\text { Laissez-Faire } \\
\text { Leadership }\end{array}$ & .605 & 1360 & .000 & .047 & .003 \\
\hline \multirow[t]{6}{*}{ Regression $2^{\mathrm{b}}$} & $\begin{array}{l}\text { Step } 1 \text { (exhibited } \\
\text { in Table 4) }\end{array}$ & .640 & 1579 & .000 & & \\
\hline & Step 2 & & & & & \multirow[b]{2}{*}{.000} \\
\hline & $\begin{array}{l}\text { Creative } \\
\text { Personality }\end{array}$ & .545 & 4258 & .000 & .554 & \\
\hline & Climate for & & & & & \multirow[t]{2}{*}{.000} \\
\hline & Creativity & .690 & 3953 & .000 & .378 & \\
\hline & $\begin{array}{l}\text { Laissez-Faire } \\
\text { Leadership }\end{array}$ & .694 & 2680 & .000 & .075 & .000 \\
\hline
\end{tabular}

${ }^{a}$ Dependent Variable is Climate for Creativity.

${ }^{\text {b }}$ Dependent Variable is Employee Creativity.

Hypothesis 3 suggested that climate for creativity mediated the relationship between leadership styles and employee creativity. As shown in Table 6, the regression coefficient for Climate for Creativity was significant in contributing to employee creativity when leadership styles were controlled, indicating the mediating role of Climate for Creativity. The significance of laissez-faire leadership decreased in step 2 whereas transformational and transactional leaderships did not enter into equation, which signified that Climate for Creativity partially mediated the relationship between leadership styles and employee creativity. Therefore, $\mathbf{H}_{3}$ is supported.

Hypothesis 4 and 5 relate to the direct effect of leadership styles on employee creativity and the moderators of this relationship. To test for moderation, Baron \& Kenny (1986) suggested moderated regression analysis: in step 1, the independent variable and the moderator were regressed on the dependent variable; then the interaction term was added into equation in step 2 . They noted that if $\Delta \mathrm{R}^{2}$ was significant when interaction term was entered significantly into the equation whereas the independent variable was insignificant, the moderator completely moderates this relationship; otherwise the moderating effect is partial. In addition to, following Aiken \& West (1991), any variable used a component of an interaction term was centered before entering it into analysis. 
Table 7. Summary of Hierarchical Regression Analyses Predicting the Moderating Role of Extrinsic Motivation in the Relation between Leadership Styles and Employee Creativity

\begin{tabular}{llccc}
\hline Variables & $\begin{array}{l}\text { Adjusted } \\
\mathbf{R}^{2}\end{array}$ & $\Delta \mathbf{R}^{2}$ & $\mathbf{F}$ & $\boldsymbol{\beta}$ \\
\hline Step 1 & & $.13^{* *}$ & & \\
Creative Personality & $.545^{* * *}$ & & $4258^{* * *}$ & $.545^{* * *}$ \\
Transformational Leadership & $.635^{* * *}$ & & $3091^{* * *}$ & $.065^{* *}$ \\
Compensation & $.659^{* * *}$ & & $2282^{* * *}$ & $-.208^{* * *}$ \\
Goal Setting & $.672^{* * *}$ & & $1818^{* * *}$ & $.130^{* * *}$ \\
Transactional Leadership & $.674^{* * *}$ & & $1466^{* * *}$ & $.130^{* * *}$ \\
Acceptance & $.675^{* * *}$ & & $1227^{* * *}$ & $.040^{* *}$ \\
\hline Step 2 & & $.036^{*}$ & & \\
Creative Personality & $.545^{* * *}$ & & $4258^{* * * *}$ & $.529^{* * *}$ \\
Transformational Leadership & $.635^{* * *}$ & & $3091^{* * * *}$ & $.084^{* * *}$ \\
Compensation & $.659^{* * *}$ & & $2282^{* * * *}$ & $-.316^{* * *}$ \\
Transactional Leadership X Compensation & $.686^{* * *}$ & & $1942^{* * * *}$ & $-.155^{* * * *}$ \\
Transactional Leadership X Acceptance & $.700^{* * *}$ & & $1657^{* * * *}$ & $.088^{* * *}$ \\
Goal Setting & $.710^{* * *}$ & & $1446^{* * * *}$ & $.132^{* * *}$ \\
Transformational Leadership X Compensation & $.710^{* *}$ & & $1244^{* * * *}$ & $-.053^{* *}$ \\
Transformational Leadership X Goal Setting & $.711^{*}$ & & $1090^{* * * *}$ & $.044^{*}$ \\
\hline
\end{tabular}

$* \mathrm{p}<0.05 \quad * * \mathrm{p}<0.01 \quad * * * \mathrm{p}<0.001$

Hypothesis 4 suggested that extrinsic motivation moderated the relationship between leadership styles and employee creativity. Table 7 shows that the regression coefficient for the interaction terms between "Transactional Leadership and Compensation", between "Transactional Leadership and Acceptance", between "Transformational Leadership and Compensation", between "Transformational Leadership and Goal Setting" were significant, thereby confirming the moderating role of Compensation between transactional leadership and employee creativity, the moderating role of Compensation between transformational leadership and employee creativity, the moderating role of Acceptance between transactional leadership and employee creativity, and the moderating role of Goal Setting between transformational leadership and employee creativity. In addition to, results show that in the presence of compensation there is a negative relationship between transactional leadership and employee creativity and between transformational leadership and employee creativity. Hence, $\mathbf{H}_{\mathbf{4}}$ is supported, since Transformational Leadership has entered into equation significantly, whereas transactional leadership did not enter into equation in step 2. 


\section{Table 8. Summary of Hierarchical Regression Analyses Predicting the Moder- ating Role of Conservation in the Relation between Leadership Styles and Em- ployee Creativity}

\begin{tabular}{llccc}
\hline Variables & $\begin{array}{l}\text { Adjusted } \\
\mathbf{R}^{2}\end{array}$ & $\Delta \mathbf{R}^{2}$ & $\mathbf{F}$ & $\boldsymbol{\beta}$ \\
\hline Step 1 & & $.095^{* *}$ & & \\
Creative Personality & $.545^{* * *}$ & & $4258^{* * * *}$ & $.635^{* * *}$ \\
Transformational Leadership & $.635^{* * *}$ & & $3091^{* * *}$ & $.197^{* * *}$ \\
Laissez-Faire Leadership & $.639^{* * *}$ & & $2096^{* * *}$ & $.082^{* * *}$ \\
Transactional Leadership & $.640^{* *}$ & & $1579^{* * *}$ & $.070^{* *}$ \\
\hline Step 2 & & $.002^{* * *}$ & & \\
Creative Personality & $.545^{* * *}$ & & $4258^{* * *}$ & $.634^{* * *}$ \\
Transformational Leadership & $.635^{* * *}$ & & $3091^{* * * *}$ & $.204^{* * *}$ \\
Laissez-Faire Leadership & $.639^{* * *}$ & & $2096^{* * * *}$ & $.084^{* * *}$ \\
Transformational Leadership X Conservation & $.640^{* * *}$ & & $1580^{* * * *}$ & $.041^{* * *}$ \\
Transactional Leadership & $.642^{* * *}$ & & $1271^{* * * *}$ & $.078^{* * *}$ \\
\hline
\end{tabular}

$* \mathrm{p}<0.05 \quad * * \mathrm{p}<0.01 \quad * * * \mathrm{p}<0.001$

Hypothesis 5 suggested that conservation moderated the relationship between leadership styles and employee creativity. Table 8 shows that the regression coefficient for the interaction term between Transformational Leadership and Conservation was significant, thereby confirming the moderating role of compensation between transformational leadership and employee creativity. Therefore, $\mathbf{H}_{\mathbf{5}}$ is supported, since all of the leadership styles have entered into equation significantly in step 2.

\section{RESULTS AND DISCUSSION}

In this study, the effects of leadership styles on employee creativity were investigated with a comprehensive model at the enterprises of Iron and Steel, Automotive and Textile industries listed in Istanbul Chamber of Industry's Turkey's Top 500 Industrial Enterprises 2008. As the results of analyses, transformational, transactional and laissez-faire leadership styles have effect on employee creativity (64\%), controlling creative personality. The findings reveal that especially transformational leadership style has important, positive effect on employee creativity (5\%) and this finding is consistent with previous findings of Jung's (2000), Shin \& Zhou's (2003) and Gumusluoglu \& Ilsev's (2009) studies. According to this study's another valuable finding, employee creativity is higher under the transformational than transactional leader condition, and this finding is consistent with previous findings of Jung's (2000) study. Also results show that creative personality had a strong explanatory effect on employee creativity $(54,5 \%)$ and this finding is consistent with previous findings of Oldham \& Cumming's (1996) study. Therefore, the existence of explanatory powers of the personality on the creativity clearly supports the argument that the personality should not be ignored in the creativity and so management field. In revealing the creative behaviors that are in compliance with the terms and conditions within this context, the personality characteristics possessed by employees should be taken into consideration in the selection of employees. Hence, in this challenging world, enterprises compete with their employees because they are seen as key indicators of intellectual capital, and so important resources of gaining and sustaining competitive advantage. This study's another contribution to the creativity, leadership and management literature is, the po- 
tential mediating role of intrinsic motivation was empirically tested. Results show that, "Challenge \& Enjoyment" partially mediated the relationship between leadership styles and employee creativity, and had an explanatory power $16,9 \%$, in other words it increased employee creativity $16,9 \%$. This finding is consistent with Prabhu, Sutton \& Sauser's (2008) and Shin \& Zhou's (2003) studies showing a partial mediating effect of intrinsic motivation. In addition to, mediating role of climate for creativity was empirically tested and it was seen that Climate for Creativity partially mediated the relationship between leadership styles and employee creativity, and it increased employee creativity $14,9 \%$. This finding is consistent with Scott \& Bruce's (1994) study showing partial mediating effect of Climate for Creativity. On the other hand, moderating role of extrinsic motivation was tested and it was seen that Compensation partially moderated between transactional leadership and employee creativity and between transformational leadership and employee creativity; Acceptance partially moderated between transactional leadership and employee creativity, and Goal Setting partially moderated between transformational leadership and employee creativity. Results also show that Compensation had a negative association with creativity. In line with the findings of Prabhu, Sutton \& Sauser (2008), this research supported extrinsic motivation factors could have both negative and positive effect on creativity changing due to situation. Finally, moderating role of conservation was tested and it was seen that Conservation partially moderated between transformational leadership and employee creativity and it increased employee creativity $9,7 \%$. This finding is consistent Jung \& Avolio's (1999) and Shin \& Zhou's (2003) determination.

This study's theoretical contribution is examination of effects of leadership styles on employee creativity in a comprehensive model; proposing new mediating and moderating variables in this correlation and filling this gap in the research. Furthermore, this study's practical contribution is there is lack of research that consists of stated variables in our model conducted such a wide scope. And finally, this study offers a methodological contribution to empirical studies on employee creativity under different leadership styles to developing countries like Turkey, as it shows the external validity of these theories which were developed and investigated in Western developed countries.

The results of this study provide important insights about the factors related to the effects of leadership styles on employee creativity. Future studies should focus on exploring this important topic in different cultures and across different types of organizations. Furthermore, such studies should seek to employ quantitative as well as qualitative methods to determine the effects of leadership styles on employee creativity proposing different mediating variables such as cognitive styles of employees, and job complexity and moderating variables such as time pressure in addition to this study's research model. 


\section{REFERENCES}

Aiken, Leona S. and West, Stephen G. (1991), Multiple Regression: Testing and Interpreting Interactions, Newbury Park: Sage Publications, Inc.

Amabile, T. M. (1983), The Social Psychology of Creativity, New York: Springer-Verlag.

Amabile, T. M. (1988), A Model of Creativity and Innovation in Organizations, Research in Organizational Behavior, 10, 123-168.

Amabile, T. M. (1998), How to Kill Creativity, Harvard Business Review, Vol. 76(5), 77-87.

Amabile, T. M., Conti, R., Coon, H., Lazenby, J. and Herron, M. (1996) Assesing the Work Environment for Creativity, Academy of Management Journal, Vol. 39(5), 1154-1184.

Amabile, T. M., Hill, K. G., Hennessey, B. A., and Tighe, E. M. (1994), The Work Preference Inventory: Assesing Intrinsic and Extrinsic Motivational Orientations, Journal of Personality and Social Psychology, Vol. 66(5), 950-967.

Baron, R. M. and Kenny, D.A. (1986), The Moderator-Mediator Variable Distinction in Social Psychological Research: Conceptual, Strategic and Statistical Considerations, Journal of Personality and Social Psychology, Vol. 51(6), 1173-1182.

Bass, Bernard M. (1985), Leadership and Performance Beyond Expectations, New York: The Free Press.

Bass, Bernard M. (1990), From Transactional to Transformational Leadership: Learning to Share The Vision, Organizational Dynamics, Vol.19(3), 19-32.

Bass, Bernard M. and Avolio, Bruce J. (1994), Improving Organizational Effectiveness Through Transformational Leadership, Thousand Oaks, CA: Sage Publications, Inc.

Bass, Bernard M. and Avolio, Bruce J. (1995), Multifactor Leadership Questionnaire, $2^{\text {nd }}$ Edition. Redwood City, CA: Mind Garden.

Boune, Louis E. and Kurtz, David L. (1990), Contemporary Business, $6^{\text {th }}$ Edition. Orlando: The Dryden Press.

Burns, J. M. (1978), Leadership, New York: Harper \& Row.

Cook, Curtis W., Hunsaker, Philip L. and Coffey, Robert E. (1997), Management and Organizational Behaviour, $2^{\text {nd }}$ Edition. U.S.A.: Irwin-Mc GrawHill.

Deci, E. L. (1971), Effects of Externally Mediated Rewards on Intrinsic Motivation, Journal of Personality and Social Psychology, Vol. 18, 105-115.

Deci, E. L. and Ryan, R. M. (1985), Intrinsic Motivation and Self-Determination in Human Behavior, New York: Plenum.

Eisenberger, R. and Rhoades, L. (2001), Incremental Effects of Reward On Creativity, Journal of Personality and Social Psychology, Vol. 81, 728-741. 
Eisenberger, R., Rhoades, L. and Cameron, J. (1999), Does Pay For Performance Increase or Decrease Perceived Self-Determination and Intrinsic Motivation?, Journal of Personality and Social Psychology, Vol. 77, 1026-1040.

Ford, C. M.,and Gioia, D. A. (1995), Multiple Visions And Multiple Voices: Academic And Practitioner Conceptions of Creativity In Organizations. In C. M. Ford \& D. A. Gioia (Eds.), Creative Action In Organizations: Ivory Tower Visions And Real World Voices (pp. 3-11). Thousand Oaks, CA: Sage Publications.

Gough, H. G. (1979), A Creative Personality Scale for the Adjective Check List, Journal of Personality and Social Psychology, Vol. 37(8), 1398-1405.

Greenberg, Jerald and Baron, Robert A, (2000), Behaviour in Organisations, $7^{\text {th }}$ Edition, New Jersey: Prentice Hall, Inc.

Gumusluoglu, Lale and Ilsev, Arzu, (2009), Transformational Leadership, Creativity, and Organizational Innovation, Journal of Business Research, Vol. 62, 461-473.

Gupta, A. and A. Singhal (1993), Managing Human Resources for Innovation and Creativity, Research Technology Management, 36, 3.

Hartog, D. and Van Muijen, J. (1997), Transactional Versus Transformational Leadership: An Analysis of the MLQ, Journal of Occupational and Organizational Psychology, Vol. 70(1), 19-25.

Jung, D. I., and Avolio, B. J. (1999), Effects of Leadership Style and Followers' Cultural Orientation on Performance in Group and Individual Task Conditions, Academy of Management Journal, 42, 208-218.

Jung, D. I. (2000), Transformational and Transactional Leadership and Their Effects on Creativity in Groups, Creativity Research Journal, Vol. 13(2), 185-195.

Kahai, S. S., Sosik, J. J., and Avolio, B. J. (1997), Effects of Leadership Style and Problem Structure on Work Group Process and Outcomes in an Electronic Meeting System Environment, Personnel Psychology, Vol. 50, 121-146.

Kahai, S. S., Sosik, J. J., and Avolio, B. J. (2003), Effects of Leadership Style, Anonymity, and Rewards On Creativity-Relevant Processes and Outcomes in An Electronic Meeting System Context, The Leadership Quarterly, Vol. 14, 499-524.

Kasof, J., Chen, C., Himsel, A., and Greenberger, E. (2007), Values and Creativity, Creativity Research Journal, Vol. 19(2-3), 105-122.

Kim, W. C., and Mauborgne, R. (2005), Blue Ocean Strategy: From Theory to Practice, California Management Review, 47(3), 105-121.

Lord, R. G. and Brown, D. J. (2001), Leadership, Values, and Subordinate Self-Concepts, The Leadership Quarterly, Vol. 12, 133-152.

Lowe, K. B., and Galen Kroeck, K. (1996), Effectiveness Correlates of Transformational and Transactional Leadership: A Meta-Analytic Review of the MLQ literature, The Leadership Quarterly, Vol.7(3), 385-425.

Mumford, M. D., Scott, G. M., Gaddis, B. and Strange, J. M. (2002), Leading Creative People: Or- 
chestrating Expertise and Relationships, Leadership Quarterly, 13(6), 705-750.

Muñoz-Doyague, M. F., González-Álvarez, N., and Nieto, M. (2008), An Examination of Individual Factors and Employees' Creativity: The Case of Spain, Creativity Research Journal, Vol. 20(1), 2133.

Nelson, Debra L., and Quick, James Campell. (1994), Organizational Behaviour: Foundations, Realities and Challenges, U.S.A.: West Publishing Company.

Northouse, Peter G. (2001), Leadership Theory and Practice, $2^{\text {nd }}$ Edition, U.S.A.: Sage Publications, Inc.

Oldham, G. R. and Cummings, A. (1996), Employee Creativity: Personal and Contextual Factors at Work, Academy of Management Journal, Vol. 39(3), 607-634.

Prabhu, V., Sutton, C. and Sauser, W. (2008), Creativity and Certain Personality Traits: Understanding the Mediating Effect of Intrinsic Motivation, Creativity Research Journal, Vol. 20(1), 53-66.

Ros, M., Schwartz, S. H. and Surkiss, S. (1999), Applied Psychology: An International Review, Vol. 48(1), 49-71.

Robins, J. M. and Greenland, S. (1992), Identifiability and Exchangeability for Direct and Indirect Effects, Epidemiology, Vol. 3(2), 143-155.

Schwartz, S. H. (1992), Universals In The Context and Structure of Values: Theoretical Advances and Empirical Tests in 20 Countries, In M. Zanna (Ed.), Advances in Experimental Social Psychology, Vol.25,1-65, Orlando, FL: Academic.

Schwartz, S. H. (1994), Are There Universal Aspects in Values?, Journal of Social Issues, Vol. 50 (4), 19-45.

Schwartz, S. H. (1999), A Theory of Cultural Values and Some Implications for Work, Applied Psychology, Vol. 48(1), 23-47.

Scott, S. G. and Bruce, R. A., (1994), Determinants of Innovative Behaviour: A Path Model of Individual Innovation in the Workplace, Academy of Management Journal, Vol. 37(3), 580-607.

Shin, S. J., Zhou, J. (2003), Transformational Leadership, Conservation, and Creativity: Evidence from Korea, Academy of Management Journal, Vol. 46(6), 703-714.

Siegel, S. ve Kaemmerer, W. (1978), Measuring the Perceived Support for Innovation in Organizations, Journal of Applied Psychology, Vol. 63, 553-562.

Sosik, J. J., Avolio, B. J., and Kahai, S. S. (1997), Effects of Leadership Style and Anonymity on Group Potency and Effectiveness in a Group Decision Support System Environment, Journal of Applied Psychology, 82, 89103.

Sosik, J. J., Avolio, B. J., and Kahai, S. S. (1998), Inspiring Group Creativity: Comparing Anonymous and identified electronic brainstorming. Small Group Research, 29, 3-31.

Sosik, J. J., Kahai, S. S., \& Avolio, B. J. (1998), Transformational leadership and dimensions of creativity: Motivating Idea Generation in Computer-Mediated Groups, Creativity Research Journal, $11,111-121$. 
Tierney, P., Farmer, S. M., and Graen, G. B. (1999), An Examination of Leadership and Employee Creativity: The Relevance of Traits and Relationships, Personnel Psychology, Vol. 52(3), 591-620.

Yukl, G. (1989). Managerial Leadership: A Review of Theory and Research, Journal of Management, Vol. 15(2), 251-289.

Yukl, G. (1992). Theory and Research on Leadership in Organizations. In: M.D. Dunnette, and L.M. Hough (Eds), Handbook of Industrial and Organizational Psychology, Vol. 3, (147-198), Palo Alto: Consulting Psychologists Press.

Yurtkoru, E. Serra. (2001), The Role of Leadership in the Organizational Change Process, Doctoral Dissertation, Istanbul: Marmara University, Faculty of Social Sciences, Discipline of Management and Organization.

Woodman, R. W., Sawyer, J. E., and Griffin, R. W. (1993), Toward a Theory of Organizational Creativity, Academy of Management Review, Vol. 18(2), 293-311.

Zhou, J., and George, J. M. (2003), Awakening Employee Creativity: The Role of Leader Emotional Intelligence, The Leadership Quarterly, 14(4-5), 545-568. 